\title{
Study on Risk Analysis and Decision-Making of Small- and Medium-Sized Enterprises on BP Neural Network Algorithm
}

\author{
Yongyi Li $\mathbb{D}^{1,2}{ }^{1,2}$ Jing Lu $\mathbb{D}^{3},{ }^{3}$ Quankun Jiao, ${ }^{1}$ and Kexin Cao ${ }^{1}$ \\ ${ }^{1}$ College of Information Science and Engineering, Guilin University of Technology, Guilin 541006, China \\ ${ }^{2}$ Qinzhou Key Laboratory of Big Data Resource Utilization, College of Electronic and Information Engineering, \\ Beibu Gulf University, Qinzhou 535011, China \\ ${ }^{3}$ Beibu Gulf University, Faculty of Science, Qinzhou 535011, China \\ Correspondence should be addressed to Jing Lu; 1627199668@qq.com
}

Received 27 December 2021; Accepted 22 January 2022; Published 3 March 2022

Academic Editor: Punit Gupta

Copyright (C) 2022 Yongyi Li et al. This is an open access article distributed under the Creative Commons Attribution License, which permits unrestricted use, distribution, and reproduction in any medium, provided the original work is properly cited.

\begin{abstract}
Artificial neural network algorithm has strong nonlinear mapping function. BP neural network algorithm is the representative of artificial neural network algorithm. Due to the relatively small scale of small, medium, and micro enterprises and lack of mortgage assets, the biggest market risk they usually face is credit risk. In order to avoid huge economic losses for banks, the impact of risk analysis on credit decision-making is the key. Therefore, the establishment of a scientific and complete credit risk assessment system has become the primary task. This paper mainly uses BP neural network algorithm to analyze the risk of small and medium-sized enterprises and solve the problem of credit decision-making. First, analyze the various influencing factors that cause credit risk, and layer the factors according to the degree of risk; secondly, use the fuzzy comprehensive evaluation method in mathematical modeling to rank each factor; then, use the fuzzy analytic hierarchy process to calculate the weight of each indicator factor as calculated by establishing the risk value function, using the function expression of the annual interest rate and the total credit formula to calculate the total credit, which solves the problem of the loan line of each enterprise, and use the optimal linear programming to give priority to the selection of the line and the interest rate. Enterprises: finally, for enterprises that do not have a credit rating, reasonable adjustments are made to the quota by establishing lending qualification expression, taking into account the impact of unexpected external factors, establishing an improved annual interest rate function, and achieving an optimized credit strategy through the establishment and solution of the model. The goal of optimizing credit strategy has been achieved.
\end{abstract}

\section{Introduction}

In practice, due to the relatively small scale of small, medium, and micro enterprises and lack of collateral assets [1], banks usually rely on credit policies, corporate transaction bill information, and the influence of upstream and downstream companies to provide companies with strong strength and stable supply-demand relations and provide loans and give preferential interest rates to companies with high reputation and low credit risk. Banks first evaluate the credit risk of small, medium, and micro enterprises based on their strength and reputation and then determine whether to lend and credit strategies such as loan limits, interest rates, and maturity based on factors such as credit risk.
A certain bank has a loan amount of 100,000 to 1 million yuan to an enterprise that is determined to lend; the annual interest rate is $4 \%$ to $15 \%$; and the loan period is 1 year. Relevant data include the relevant data of 123 companies with credit records, the relevant data of 302 companies without credit records, and the 2019 statistics on the relationship between loan interest rates and customer churn rates. Then, how to establish a model to study the credit strategy for small, medium, and micro enterprises based on the actual situation and the data information in the attachment has become a key issue in bank lending.

For the bank's credit strategy, the following three issues need to be addressed: 
(1) Quantify the credit risk of the 123 companies in Annex 1 and give the bank's credit strategy for these companies when the total annual credit is fixed.

(2) On the basis of question 1, conduct a quantitative analysis of the credit risk of the 302 companies in Annex 2 [2] and give the bank's credit strategy for these companies when the total annual credit is 100 million yuan.

(3) The production and operation and economic benefits of enterprises may be affected by some sudden factors, and sudden factors often have different effects on different industries and different types of enterprises. Considering the credit risk of each company in Annex 2 and the impact of possible sudden factors (such as the novel coronavirus epidemic) on each company, the bank's credit adjustment strategy when the total annual credit is 100 million yuan is given.

\section{Problems Analysis}

In response to question 1 , we are required to quantify customer credit risk. The first problem is to find out the key factors that affect credit risk. We can consider the fuzzy analytic hierarchy process [3] to establish systematization and hierarchy. In a structured system, the elements in the system are compared in pairs, and a matrix is generated for quantitative analysis. After determining the collective evaluation (level) of the credit risk factors (indicators) of 123 companies, the fuzzy priority relationship matrix is obtained through custom data, and the fuzzy judgment matrix is calculated through the formula, then the weight of each factor level is determined, and the priority is judged. The most important risk factors can be obtained.

In response to problem 2, the goal is to solve the problems of credit risk quantification, loan interest rates, and bank credit optimal strategies. Because of the relevant data and loan interest rates of 302 companies with no credit records, the risk value cannot be calculated based on the reputation rating and default. Therefore, the relationship between the average profit rate and the risk is mainly considered, and the function is obtained by fitting the data in Annex 1. This problem can be solved; use the function of problem 1 to get the annual interest rate of 203 companies; use the formula of problem 1 to calculate the quota of each enterprise, and then use the combination optimization program and planning method to adjust the credit limit.

In response to question 3, focus on the sudden factors that affect the production and operation and economic benefits of the enterprise, and use the data in Annex 2 as the basis for analysis. Several questions are mainly considered. First, why are many companies operating negatively? Second, what is the reason why the corporate credit line is not within the scope of the bank's requirements? Third, how to reduce customer churn rate? In view of the above problems, the model designed in question 1 and question 3 can be improved.

\section{Credit Strategy Based on Risk Quantitative Analysis}

For question 1 , it is necessary to find the credit factors to quantify the risk. Because the company has historical records, the fuzzy evaluation method can be considered; if the influencing factors can be determined, consider using the multiweight relationship [4] to calculate the risk value. From the risk value, the annual interest rate can be obtained by using a piecewise function or a fitting method; combined with the annual interest rate, on the basis of calculating the credit limit, linear programming and optimization methods can be used to select the optimal credit strategy.

3.1. Rating of Credit Factors. The first problem of question 1 is to find the important factors of credit evaluation. In order to select the factors that affect the credit of small and micro enterprises, the fuzzy comprehensive evaluation method is used to evaluate the credit decision, comprehensively considering various factors related to credit risk and based on indicators. The selection principle finally determines the level of the indicator system for corporate credit risk evaluation. The specific evaluation indicator structure is shown in Table 1.

Find the weights of the pairwise comparison matrix between the criterion layer and the target layer [5].

First, the criterion layer compares the target pair by pair and establishes the priority relationship matrix $G=\left(g_{i j}\right)_{n \times n}$, with $g_{i j}=(1,0.5,0)$ to establish a priority matrix:

$$
\left|\begin{array}{ccccc}
A_{1} & B_{1} & B_{2} & B_{3} & r_{1} \\
B_{1} & 0.5 & 1 & 1 & 2.5 \\
B_{2} & 0 & 0.5 & 1 & 1.5 \\
B_{3} & 0 & 0 & 0.5 & 0.5
\end{array}\right| .
$$

According to formula (2), the fuzzy judgment matrix is calculated, and then the square root method formula (3) is used to calculate the weight of the level index.

$$
\begin{aligned}
r_{i j} & =\frac{r_{i}-r_{j}}{2 n}+0.5, \\
w_{i} & =r_{i} \sum_{i=1}^{m} \bar{r}_{i}(i=1,2 \ldots \ldots m), \\
r_{i} & =\sqrt[n]{\prod_{i=1}^{n} r_{i j}}(j=1,2 \ldots \ldots m) .
\end{aligned}
$$

Second, the criterion layer establishes a fuzzy consistent judgment matrix for the target:

$$
\left|\begin{array}{ccccc}
A_{1} & B_{1} & B_{2} & B_{3} & W_{1} \\
B_{1} & 0.50 & 0.67 & 0.83 & 0.430 \\
B_{2} & 0.33 & 0.50 & 0.67 & 0.316 \\
B_{3} & 0.17 & 0.33 & 0.50 & 0.200
\end{array}\right| .
$$


TABLE 1: The structure of corporate credit evaluation indicators.

First level indicator

Enterprise's own reasons B1

Causes of corporate credit risk A1
Bank's own reasons B2

Macro factor B3
Secondary indicators

Reputation level C1

Number of violations $\mathrm{C} 2$

Bill information C3

Upstream and downstream companies influence C4 Industry risk $\mathrm{C} 1$

Professionalism of assessors C2

Enterprise size $\mathrm{C} 3$

Credit strategy $\mathrm{C} 4$

Government administrative intervention $\mathrm{C} 1$

National legal system $\mathrm{C} 2$

National economy C3

Vicious struggle between banks C4
Find the weight coefficient of the pairwise comparison matrix of the plan layer to the target layer.

First, the priority comparison matrix corresponding to the enterprise's own factor criteria is

$$
\left|\begin{array}{cccccc}
B_{1} & C_{1} & C_{2} & C_{3} & C_{4} & r_{1} \\
C_{1} & 0.5 & 1 & 1 & 1 & 3.5 \\
C_{2} & 0 & 0.5 & 0 & 1 & 1.5 \\
C_{3} & 0 & 1 & 0.5 & 1 & 2.5 \\
C_{4} & 0 & 0 & 0 & 0.5 & 0.5
\end{array}\right| .
$$

Second, the company's own factor criteria establish a fuzzy consistent judgment matrix:

$$
\left|\begin{array}{cccccc}
B_{1} & C_{1} & C_{2} & C_{3} & C_{4} & W_{2} \\
C_{1} & 0.5 & 0.75 & 0.625 & 0.875 & 1.420 \\
C_{2} & 0.25 & 0.5 & 0.375 & 0.375 & 0.768 \\
C_{3} & 0.375 & 0.625 & 0.5 & 0.75 & 1.149 \\
C_{4} & 0.125 & 0.625 & 0.25 & 0.5 & 0.663
\end{array}\right| .
$$

Then, the priority comparison matrix corresponding to the bank's own factor criteria is

$$
\left|\begin{array}{cccccc}
B_{2} & C_{1} & C_{2} & C_{3} & C_{4} & r_{3} \\
C_{1} & 0.5 & 1 & 1 & 1 & 3.5 \\
C_{2} & 0 & 0.5 & 1 & 1 & 2.5 \\
C_{3} & 0 & 0 & 0.5 & 1 & 1.5 \\
C_{4} & 0 & 0 & 0 & 0.5 & 0.5
\end{array}\right| .
$$

Then, the fuzzy consistent judgment matrix corresponding to the bank's own factor criterion is

$$
\left|\begin{array}{cccccc}
B_{2} & C_{1} & C_{2} & C_{3} & C_{4} & W_{3} \\
C_{1} & 0.5 & 0.625 & 0.75 & 0.875 & 0.894 \\
C_{2} & 0.375 & 0.5 & 0.625 & 0.75 & 0.723 \\
C_{3} & 0.25 & 0.375 & 0.5 & 0.625 & 0.976 \\
C_{4} & 0.125 & 0.25 & 0.375 & 0.5 & 1.404
\end{array}\right| .
$$

In addition, the priority comparison matrix corresponding to the macro factor criterion is

$$
\left|\begin{array}{cccccc}
B_{3} & C_{1} & C_{2} & C_{3} & C_{4} & r_{4} \\
C_{1} & 0.5 & 0.5 & 0 & 0 & 1 \\
C_{2} & 0.5 & 0.5 & 0.5 & 0 & 1.5 \\
C_{3} & 1 & 0.5 & 0.5 & 0 & 2.0 \\
C_{4} & 1 & 1 & 1 & 0.5 & 3.5
\end{array}\right| .
$$

Finally, the fuzzy discriminant matrix corresponding to the macro factor criterion is

$$
\left|\begin{array}{cccccc}
B_{3} & C_{1} & C_{2} & C_{3} & C_{4} & W_{4} \\
C_{1} & 0.5 & 0.4375 & 0.375 & 0.1875 & 0.535 \\
C_{2} & 0.5625 & 0.5 & 0.4375 & 0.25 & 1.130 \\
C_{3} & 0.625 & 0.5625 & 0.5 & 0.3125 & 1.307 \\
C_{4} & 0.8125 & 0.75 & 0.6875 & 0.5 & 1.027
\end{array}\right| .
$$

From the above calculation and analysis, it can be seen that the more weighted factors are $\mathrm{C} 2$ and $\mathrm{C} 4$ in $\mathrm{B} 2$; that is, the credit risk is mainly determined by the credit rating and bill information of the company's own factors, and C1 (national economy) is also affected by B3 (macro factor) [6] and other factors.

$$
V_{i j}=w_{i} \times w_{i j}
$$

From formula (12), it can be concluded that the ranking of the influence of each factor on the credit decision of the enterprise is shown in Table 2.

3.2. Calculation of Risk Value Based on Multiweight Relationship. The quantitative analysis of the credit risk $\mathrm{G}$ of the 123 companies in Annex 1 is as follows.

First, construct the weight term sum risk value function, as shown in

$$
\begin{aligned}
G & =P \times P_{3}+D \times P_{1}+W \times P_{2}, \\
P & =\frac{S-C}{4},
\end{aligned}
$$


TABLE 2: Weights of corporate credit evaluation indicators [7].

First level indicator

Own cause B1

Causes of corporate credit risk A1
Secondary indicators

Reputation level C1

Number of violations C2

Bill information C3

Upstream and downstream companies influence C4 Industry risk $\mathrm{C} 1$

Professionalism of assessors C2

Enterprise size C3

Credit strategy $\mathrm{C} 4$

Government administrative intervention $\mathrm{C} 1$

National legal system C2

National economy C3

Vicious struggle between banks C4
Weight $\mathrm{w}$

1.420

0.768

1.149

0.663

0.894

0.723

0.976

1.404

0.535

1.130

1.307

1.027

$$
\begin{gathered}
D= \begin{cases}0.9 & C_{1}=A \\
0.7 & C_{1}=B \\
0.5 & C_{1}=C \\
0 & C_{1}=D\end{cases} \\
W=\left\{\begin{array}{ll}
0 & \text { breach of contract } \\
1 & \text { no breach of contract }
\end{array} .\right.
\end{gathered}
$$

Among them, formula (14) is to calculate the average annual profit rate.

Then, use Excel to calculate the profit of each company $=$ total expenditure (tax included)-total income (after tax). The total expenditure (including tax) here $=$ SUMIFS (input invoice information! \$G\$2:\$G\$210948, input invoice information! \$A \$2:\$A210948, A2, input invoice information! \$H\$2:\$H 210948 , "Valid invoice"), Total income (after $\operatorname{tax})=$ SUMIFS (output invoice information! \$E\$2: \$E\$162486, output invoice information! \$A2: \$A \$162486, A2, output invoice information! $\$ H \$ 2$ : $\$ H \$ 162486$, "Valid invoice").

Finally, by using formulas (13)-(16) to calculate, finally calculate the risk $Y$. Specific data are shown in Table 3.

3.3. Calculate the Annual Interest Rate. After calculating the risk value in Annex 1, the evenly distributed risk value range is $[0,9.21]$. According to the data in Annex, the value difference of the annual interest rate is 0.004 . Therefore, the corresponding value of the risk value and the annual interest rate is obtained as shown in Table 4.

Perform data fitting on the data in Table 1 to obtain the calculated annual interest rate function, as shown in formula (22), and the specific annual interest rate is shown in Table 5.

$$
\begin{gathered}
Z=E+Q, \\
E=\frac{Y \times\left(1-Y_{2}\right)}{I}, \\
G_{2}=\frac{R-J}{J}, \\
I=T-U, \\
Q=E \times P_{i}, \\
y=1 E-05 x^{2}-0.0122 x+0.1505 .
\end{gathered}
$$

Calculate the total credit $Z$ of the enterprise by formulas (17)-(21).

Use goal planning [8] to judge whether to lend to enterprises under the condition of maximizing the interests of banks:

$$
E(x)=\max \sum_{i=1}^{n} Y_{i} x_{i}\left(1+Y_{i}\right) M_{i}
$$

Among them,

$$
M_{i}=\left\{\begin{array}{ll}
0 & \text { credit rating is D } \\
1 & \text { the credibility level is atleast C }
\end{array}, \quad 10 \leq Y_{i} x_{i} \leq G_{i} \leq 0.15 .\right.
$$

3.4. Calculate the Credit Limit of Each Company. $x_{i}$ represents the loan amount, corporate credit line = last year's sales revenue $\times(1$-previous year's sales profit rate $) \times(1+$ estimated sales revenue growth rate $) /$ number of capital turnover. Among them, the number of turnover = accounts receivable turnover days-accounts payable turnover days, the credit limit in 2021 is determined by calculating the 19-20 income growth rate and the number of capital turnover [9]. The specific data is shown in Table 6.

Through the above quantification of credit risk, the annual credit interest rate and credit limit can be calculated, and then the target planning model analysis can be used to obtain the credit strategy. First, if the bank wants to insure the collection, it can consider giving priority to mortgage 
TABLE 3: Sample table of enterprise risk value data.

\begin{tabular}{|c|c|c|c|c|c|c|c|}
\hline $\begin{array}{l}\text { Enterprise } \\
\text { code }\end{array}$ & Company name & $\begin{array}{l}\text { Reputation } \\
\text { rating }\end{array}$ & $\begin{array}{c}\text { Rank } \\
\text { weight }\end{array}$ & $\begin{array}{c}\text { Breach of } \\
\text { contract }\end{array}$ & $\begin{array}{l}\text { Default } \\
\text { weight }\end{array}$ & $\begin{array}{l}\text { Average annual } \\
\text { profit rate }\end{array}$ & Risk \\
\hline E1 & $\begin{array}{l}{ }^{* * *} \text { Electric Appliance Sales } \\
\text { Co., Ltd. }\end{array}$ & A & 0.9 & No & 1 & -0.3874844 & 0.688335602 \\
\hline E2 & ${ }^{* * *}$ Technology Co., Ltd. & $\mathrm{A}$ & 0.9 & No & 1 & 2.63621849 & 2.182256471 \\
\hline E3 & $\begin{array}{l}* * * \text { Electronics (China) Co., } \\
\text { Ltd. }{ }^{* * *} \text { Branch }\end{array}$ & $\mathrm{C}$ & 0.5 & No & 1 & 9.52389829 & 5.341012428 \\
\hline E4 & $\begin{array}{l}\text { *** Development Limited } \\
\text { Liability Company }\end{array}$ & $\mathrm{C}$ & 0.5 & No & 1 & 6.22735183 & 3.71228772 \\
\hline E5 & $\begin{array}{l}{ }^{* * *} \text { Supply Chain Management } \\
\text { Co., Ltd. }\end{array}$ & B & 0.7 & No & 1 & -0.1086503 & 0.703979141 \\
\hline E6 & $\begin{array}{l}{ }^{* * *} \text { Decoration Design } \\
\text { Engineering Co., Ltd }\end{array}$ & A & 0.9 & No & 1 & 0.14092075 & 0.949404716 \\
\hline E7 & $\begin{array}{l}{ }^{* * *} \text { Home Appliances Co., Ltd. } \\
*_{* * *} \text { Branch }\end{array}$ & A & 0.9 & No & 1 & 7.07898782 & 4.377295512 \\
\hline
\end{tabular}

TABLE 4: Corresponding value of risk value and annual interest rate.

\begin{tabular}{lccccc}
\hline Value at risk & Annual interest rate & Value at risk & Annual interest rate & Value at risk & Annual interest rate \\
\hline 9.21 & 0.04 & 5.920714286 & 0.0785 & 2.631428571 & 0.1185 \\
8.881071429 & 0.0425 & 5.591785714 & 0.0825 & 2.3025 & 0.1225 \\
8.552142857 & 0.0465 & 5.262857143 & 0.0865 & 1.973571429 & 0.1265 \\
8.223214286 & 0.0505 & 4.933928571 & 0.0905 & 1.644642857 & 0.1305 \\
7.894285714 & 0.0545 & 4.605 & 0.0945 & 0.986785714 & 0.1345 \\
7.565357143 & 0.0585 & 4.276071429 & 0.0985 & 0.657857143 & 0.1385 \\
7.236428571 & 0.0625 & 3.947142857 & 0.1025 & 0.328928571 & 0.1425 \\
6.9075 & 0.0665 & 3.618214286 & 0.1065 & 0.1105 & 0.15 \\
6.578571429 & 0.0705 & 3.289285714 & 0.1145 & \\
6.249642857 & 0.0745 & 2.960357143 & &
\end{tabular}

TABle 5: Sample table of corporate annual interest rate data.

\begin{tabular}{|c|c|c|c|c|c|c|c|}
\hline $\begin{array}{l}\text { Enterprise } \\
\text { code }\end{array}$ & Company name & $\begin{array}{l}\text { Reputation } \\
\text { rating }\end{array}$ & $\begin{array}{c}\text { Rank } \\
\text { weight }\end{array}$ & $\begin{array}{c}\text { Breach of } \\
\text { contract }\end{array}$ & $\begin{array}{l}\text { Default } \\
\text { weight }\end{array}$ & Risk & $\begin{array}{l}\text { Annual interest } \\
\text { rate }\end{array}$ \\
\hline E1 & $\begin{array}{l}\text { ***Electric Appliance Sales Co., } \\
\text { Ltd. }\end{array}$ & A & 0.9 & No & 1 & 0.688335602 & 0.142107044 \\
\hline E2 & ***Technology Co., Ltd. & A & 0.9 & No & 1 & 2.182256471 & 0.123924093 \\
\hline E3 & $\begin{array}{l}* * * \text { Electronics (China) Co., Ltd. } \\
{ }_{* * *} \text { Branch }\end{array}$ & $\mathrm{C}$ & 0.5 & No & 1 & 5.341012428 & 0.085624913 \\
\hline $\mathrm{E} 4$ & $\begin{array}{l}{ }^{* * *} \text { Development Limited } \\
\text { Liability Company }\end{array}$ & $\mathrm{C}$ & 0.5 & No & 1 & 3.71228772 & 0.105347901 \\
\hline E5 & $\begin{array}{l}{ }^{* * *} \text { Supply Chain Management } \\
\text { Co., Ltd. }\end{array}$ & B & 0.7 & No & 1 & 0.703979141 & 0.14191641 \\
\hline$\ldots$ & $\ldots$ & & $\ldots$ & $\ldots$ & $\ldots$ & $\ldots$ & \\
\hline
\end{tabular}

TABle 6: Sample table of corporate credit line data.

\begin{tabular}{|c|c|c|c|c|c|c|c|}
\hline $\begin{array}{l}\text { Enterprise } \\
\text { code }\end{array}$ & Company name & Risk & $\begin{array}{l}2020 \text { income } \\
\text { (after tax) }\end{array}$ & $\begin{array}{l}2020 \text { profit } \\
\text { margin }\end{array}$ & $\begin{array}{l}\text { 19-20 revenue } \\
\text { growth rate }\end{array}$ & Turnover & $\begin{array}{c}2021 \\
\text { quota }\end{array}$ \\
\hline E1 & $\begin{array}{c}\text { ***Electric Appliance Sales } \\
\text { Co., Ltd. }\end{array}$ & 0.688335602 & 73231470 & -0.2228772 & -0.95 & 94 & 48151.8 \\
\hline E2 & ${ }^{* * *}$ Technology Co., Ltd. & 2.182256471 & 49935565 & 4.35035404 & -0.81 & -700 & 45669.9 \\
\hline E3 & $\begin{array}{l}{ }^{* * *} \text { Electronics (China) Co., } \\
\text { Ltd. }{ }^{* * *} \text { Branch }\end{array}$ & 5.341012428 & 15380416.5 & 20.3692017 & -0.89 & 335 & 97897.7 \\
\hline
\end{tabular}


loans for enterprises with low risk. Choose companies with high annual interest rates; second, if banks want to maximize their benefits, they can expand credit lines or regulate annual interest rates for companies with high credit risks to maximize their annual returns.

\section{Credit Strategy for Companies with No Credit History}

For problem 2 the main solution is to carry out risk quantification, loan interest rate and bank credit optimal strategy for enterprises without credit records.

4.1. Quantify the Credit Risk of Companies with No Credit History. Because of the relevant data and loan interest rates of 302 companies with no credit records, the risk value cannot be calculated based on the credit rating and default or not. Therefore, the relationship between the average profit rate and the risk is mainly considered [10]; by fitting the data in Annex 1, the derived function can solve the problem.

First, determine the annual interest rate according to the method in question 1 . The process is as follows.

First, use formula (25) and formula (26) to calculate the total expenditure (including tax) and total income (after tax) of each enterprise, then calculate the profit, and finally, use formula (27) to calculate the average profit of each enterprise rate.

$$
Z(i)=\sum_{j=1}^{k} Q(i)(j) .
$$

Among them, $i=E 124, E 125, \ldots, E 425, Q$ is the amount of the input invoice, and $j$ is the serial number of the input invoice of the $i$ enterprise.

$$
S(i)=\sum_{j=1}^{m} G(i)(j) .
$$

Among them, $i=E 124, E 125, \ldots, E 425, G$ is the total fare tax on output, and $j$ is the serial number of the output invoice of enterprise $i$.

$$
A(i)=\frac{G(i)(j)-Q(i)(j)}{Q(i)(j) / n} .
$$

Among them, $i=E 124, E 125, \ldots, E 425$, and $n$ is the number of effective operating years.

Second, from the data relationship between the annual profit rate and the risk value in Annex 1, the risk value function is fitted by fitting: $y=-8 E-09 x^{2}+0.4941 x+0.6467$, and the specific risk value is shown in Table 6 and Table 7.

4.2. Calculate the Annual Interest Rate. Using problem 1 function $y=1 E-05 x 2-0.0122 x+0.150$ to get the annual interest rate of 203 companies, the data sample table is shown in Table 8.
4.3. Credit Line Adjustment Strategy. Calculate the quota of each enterprise using the formula for calculating quota in question 1, and then adjust the quota according to the total amount of 100 million.

Strategy 1: select the legal limit range $(100,000$ to 1 million) and companies with purchase and sales data in 2020. Companies with low risk and high returns are preferred. Use the C\# program to obtain the business portfolio and its credit line according to the conditions, and get the total amount of loans. The total income is 3497942.5 yuan, and the total income is 383611.8845 yuan. The specific data is shown in Table 9. This strategy minimizes the risk of repayment and maximizes the income of the lending bank, but it cannot meet the condition of a total loan of 100 million yuan.

Strategy 2: choose a company with purchase and sales data in 2020, with low risk and high return priority. In order to solve the problem of strategy 1 , expand the scope of the line, use the C\# program to obtain the business portfolio and its credit line according to the conditions, and get the total loan amount of 83966019.96. The total income is $919,9847.981$ yuan. The specific data is shown in Table 10. This strategy expands the quota range to $10,000 \sim 40,000,000$ yuan, minimizes the risk of repayment, and maximizes the income of the loan bank. According to the optimal linear programming method [11], run the C\# program to achieve the goal of the total loan amount closest to 100 million.

\section{Improvement of Credit Strategy Based on Emergencies}

Question 3 needs to consider the unexpected factors that affect the company's production and operation and economic benefits. By calculating the purchase and sales invoice data of each company in Annex 2, we found the following problems:

(1) Affected by the new crown virus epidemic in 2020, many companies will experience negative growth in their operations

(2) The credit line of the enterprise is not within the range required by the bank

(3) Excessive annual corporate credit interest rates may cause serious loss of customers

In view of the above analysis, these problems can be solved through strategies such as focusing on assessing the changes in the company's purchase and sales invoice data in 2019, adjusting the credit limit, and improving the calculation method of the annual interest rate.

5.1. Reassessment of Companies That Have No Record of Purchase and Sales Invoices in 2020. Focus on assessing the data of purchase and sales invoices in 2019, and calculate the profit growth rate from 2018 to 2019. This is the credit reference for 2021. The formula in Excel changes to: $=$ COUNTIFS $($ output invoice information! \$A \$2: \$A $\$ 162486$, A2, output invoice information! $\$ \mathrm{H} \$ 2$ : $\$ \mathrm{H} \$ 162486$, "valid invoice", output invoice information!I\$2: 
TABLE 7: Sample table of process data for calculating Annex 2 risk value.

\begin{tabular}{lccccc}
\hline Enterprise code & Company name & Risk & Total expenditure & Total income & Average annual profit rate \\
\hline E124 & Self-employed E124 & 0.586753595 & 844202797.2 & 741780368 & -0.1213244 \\
E125 & Self-employed E125 & 0.617094302 & 1001201809 & 941211364 & -0.0599184 \\
E126 & Self-employed E126 & 2.149774437 & 128818723.6 & 520691098 & 3.04204516 \\
E127 & Self-employed E127 & 182.5994278 & 1765558.94 & 651937955 & 368.253011 \\
\hline
\end{tabular}

TABLE 8: 203 corporate annual interest rate data sample table.

\begin{tabular}{llcr}
\hline Enterprise code & Company name & Risk & Annual interest rate \\
\hline E124 & Self-employed E124 & 0.586753595 & 0.143345049 \\
E125 & Self-employed E125 & 0.617094302 & 0.142975258 \\
E126 & Self-employed E126 & 2.149774437 & 0.124318967 \\
\hline
\end{tabular}

TABle 9: 203 corporates' loan strategy data.

\begin{tabular}{|c|c|c|c|c|c|}
\hline Enterprise code & Company name risk & Risk & Annual interest rate & 2021 quota & Income \\
\hline E149 & ${ }^{* * *}$ Construction labor Service Co., Ltd. & 78.6259881 & 0.04 & 140987.6 & 5639.5052 \\
\hline E176 & *** Technology Co., Ltd. & 8.778604263 & 0.044171667 & 157082.4 & 6938.5915 \\
\hline E144 & ${ }^{* * *}$ Labor Service Co., Ltd. & 5.662303789 & 0.081740511 & 220474.2 & 18021.67 \\
\hline E392 & ***Technology Co., Ltd. & 5.461949443 & 0.084162546 & 146091.3 & 12295.419 \\
\hline E234 & ${ }^{* * *}$ Mechanical and Electrical Equipment Trading Co., Ltd. & 4.086490945 & 0.100811805 & 378987.4 & 38206.4 \\
\hline E303 & ${ }^{* * *}$ Book Distribution Co., Ltd. & 3.486049648 & 0.10809172 & 886724.1 & 95847.533 \\
\hline E243 & *** Technology Co., Ltd. & 3.392272855 & 0.109229346 & 207823.5 & 22700.43 \\
\hline E407 & ${ }^{* * *}$ Decoration Engineering Co., Ltd. & 2.374062469 & 0.1215928 & 238903.3 & 29048.921 \\
\hline E302 & ${ }^{* * *}$ Electromechanical Equipment Co., Ltd. & 1.476475579 & 0.132508798 & 275226.5 & 36469.927 \\
\hline E307 & ${ }^{* * *}$ Communication Engineering Co., Ltd. & 1.091490391 & 0.137195731 & 128036.2 & 17566.024 \\
\hline E313 & ${ }^{* * *}$ Logistics Co., Ltd. & 0.955389312 & 0.138853378 & 122741.0 & 17043.004 \\
\hline E232 & ${ }^{* * *}$ Investment Development Co., Ltd. & 0.784912808 & 0.140930225 & 594865.0 & 83834.46 \\
\hline
\end{tabular}

TABLE 10: 203 corporates' loan strategy 2 data.

\begin{tabular}{|c|c|c|c|c|c|}
\hline Enterprise code & Company name & Risk & Annual interest rate & 2021 quota & Income \\
\hline E343 & ${ }^{* * *}$ Hardware Tools Business Department & 1501.178169 & 0.04 & 14834298.2 & 593371.9 \\
\hline E359 & ${ }^{* * *}$ Kitchen Supplies Business Department & 1050.753956 & 0.04 & 2924976.0 & 116999 \\
\hline E375 & ${ }^{* * *}$ Electrical Department & 870.0656293 & 0.04 & 302790.5 & 12111.62 \\
\hline E382 & ${ }^{* * *}$ Education Information Consulting Co., Ltd. ${ }^{* * *}$ Branch & 335.911581 & 0.04 & 935355.9 & 37414.23 \\
\hline E215 & ${ }^{* * *}$ Construction Engineering Co., Ltd. & 139.7314732 & 0.04 & 57732.1 & 2309.285 \\
\hline E149 & ${ }^{* * *}$ Construction Labor Service Co., Ltd. & 78.6259881 & 0.04 & 140987.6 & 5639.5052 \\
\hline E422 & ${ }^{* * *}$ Children's Clothing Store & 14.05858053 & 0.04 & 125885.8 & 5035.43 \\
\hline E399 & ${ }^{* * *}$ Decoration Engineering Co., Ltd. & 10.98344746 & 0.04 & 237148.3 & 9485.9306 \\
\hline E176 & ${ }^{* * *}$ Technology Co., Ltd. & 8.778604263 & 0.044171667 & 157082.4 & 6938.5915 \\
\hline E144 & *** Labor Service Co., Ltd. & 5.662303789 & 0.081740511 & 220474.2 & 18021.67 \\
\hline E392 & *** Technology Co., Ltd. & 5.461949443 & 0.084162546 & 146091.3 & 12295.419 \\
\hline E413 & ${ }^{* * *}$ Stone Crafts Co., Ltd. & 5.357296826 & 0.085427985 & 99596.6 & 8508.336 \\
\hline E254 & ***Equipment Installation Engineering Co., Ltd. & 5.238550658 & 0.086864106 & 1193160.7 & 103642.8 \\
\hline E362 & *** Building Materials Co., Ltd. & 4.730884788 & 0.093007018 & 2039255.1 & 189665 \\
\hline E210 & ${ }^{* * *}$ Construction Engineering Co., Ltd. & 4.443812652 & 0.09648296 & 25676.5 & 2477.342 \\
\hline E234 & ${ }^{* * *}$ Mechanical And Electrical Equipment Trading Co., Ltd. & 4.086490945 & 0.100811805 & 378987.4 & 38206.4 \\
\hline E398 & *** Medical Management Consulting Co., Ltd. & 3.936529644 & 0.102629301 & 160134.2 & 16434.462 \\
\hline E303 & ***B Book Distribution Co., Ltd. & 3.486049648 & 0.10809172 & 886724.1 & 95847.533 \\
\hline E243 & ${ }^{* * *}$ Technology Co., Ltd. & 3.392272855 & 0.109229346 & 207823.5 & 22700.43 \\
\hline E415 & ${ }^{* * *}$ Advertising Design Service Department & 2.494874076 & 0.12012478 & 40176.9 & 4826.241 \\
\hline E315 & ${ }^{* * *}$ Tire Co., Ltd. & 2.465996416 & 0.120475655 & 15648.5 & 1885.268 \\
\hline E407 & ${ }^{* * *}$ Decoration Engineering Co., Ltd. & 2.374062469 & 0.1215928 & 238903.3 & 29048.921 \\
\hline E409 & ${ }^{* * *}$ Plastic Co., Ltd. & 2.304318966 & 0.122440407 & 14148.8 & 1732.382 \\
\hline E406 & ***Tendering Agency Co., Ltd. & 2.227985901 & 0.123368211 & 4772155.3 & 588732.3 \\
\hline E250 & ${ }^{* * *}$ Plastic Factory & 1.82336773 & 0.12828816 & 48162.6 & 6178.688 \\
\hline E354 & ***Advertising Co., Ltd. & 1.803160504 & 0.128533956 & 10605.9 & 1363.223 \\
\hline
\end{tabular}


TABle 10: Continued.

\begin{tabular}{|c|c|c|c|c|c|}
\hline Enterprise code & Company name & Risk & Annual interest rate & 2021 quota & Income \\
\hline E372 & ${ }^{* * *}$ Auto Repair Co., Ltd. & 1.779281527 & 0.128824424 & 26574.1 & 3423.388 \\
\hline E276 & ${ }^{* * *}$ Sports Facilities Engineering Co., Ltd. & 1.555535584 & 0.131546663 & 18595.4 & 2446.165 \\
\hline E298 & *** Electrical Maintenance Service Co., Ltd. & 1.547518376 & 0.131644224 & 13606.4 & 1791.204 \\
\hline E302 & ${ }^{* * *}$ Electromechanical Equipment Co., Ltd. & 1.476475579 & 0.132508798 & 275226.5 & 36469.927 \\
\hline E256 & ${ }^{* * *}$ Materials Co., Ltd. & 1.393742208 & 0.13351577 & 94308.9 & 12591.72 \\
\hline E305 & *** Labor Service Co., Ltd. & 1.360741454 & 0.13391747 & 8349441.3 & 1118136 \\
\hline E355 & ${ }^{* * *}$ Carpet Business Department & 1.264860734 & 0.135084698 & 38700704.4 & 5227873 \\
\hline E171 & ${ }^{* * *}$ Quality Inspection And Testing Station & 1.256349819 & 0.135188316 & 27279.9 & 3687.92 \\
\hline E393 & *** Commercial And Trade Limited Company & 1.186267081 & 0.136041614 & 892782.4 & 121455.6 \\
\hline E307 & ${ }^{* * *}$ Communication Engineering Co., Ltd. & 1.091490391 & 0.137195731 & 128036.2 & 17566.024 \\
\hline E347 & ${ }^{* * *}$ Stainless Steel Material Co., Ltd. & 1.084168799 & 0.137284895 & 2967322.6 & 407368.6 \\
\hline E249 & ${ }^{* * *}$ Construction Engineering Co., Ltd. & 1.054026283 & 0.137651989 & 64464.9 & 8873.723 \\
\hline E313 & *** Logistics Co., Ltd. & 0.955389312 & 0.138853378 & 122741.0 & 17043.004 \\
\hline E335 & ${ }^{* * *}$ Excavator Leasing Operation Department & 0.900990849 & 0.139516029 & 1112123.0 & 155159 \\
\hline E397 & ${ }^{* * *}$ Hairy Crab Business Department & 0.878407001 & 0.139791151 & 118020.2 & 16498.186 \\
\hline E361 & ${ }^{* * *}$ Survey And Design Engineering Co., Ltd. & 0.878205611 & 0.139793604 & 13616.8 & 1903.548 \\
\hline E169 & ${ }^{* * *}$ Architectural Design Co., Ltd. & 0.867856955 & 0.139919677 & 29880.3 & 4180.849 \\
\hline E160 & ${ }^{* * *}$ Steel Structure Engineering Co., Ltd. & 0.800656764 & 0.140738398 & 13465.4 & 1895.099 \\
\hline E232 & ${ }^{* * *}$ Investment Development Co., Ltd. & 0.784912808 & 0.140930225 & 594865.0 & 83834.46 \\
\hline E279 & ${ }^{* * *}$ Environmental Packaging Co., Ltd. & 0.755090716 & 0.141293595 & 28942.8 & 4089.433 \\
\hline E334 & *** Mechanical Technology Co., Ltd. & 0.743188632 & 0.141438622 & 76938.9 & 10882.13 \\
\hline E297 & ${ }^{* * *}$ Construction Machinery Leasing Co., Ltd. & 0.723080704 & 0.141683644 & 32156.6 & 4556.064 \\
\hline E300 & ${ }^{* * *}$ Construction Engineering Co., Ltd. & 0.720388899 & 0.141716445 & 30338.3 & 4299.442 \\
\hline E293 & ${ }^{* * *}$ Materials Co., Ltd. & 0.596137139 & 0.143230681 & 20606.9 & 2951.545 \\
\hline
\end{tabular}

TABLE 11: Growth rate of revenue of some enterprises in 2020.

\begin{tabular}{|c|c|c|c|c|c|c|c|}
\hline $\begin{array}{l}\text { Enterprise } \\
\text { code }\end{array}$ & Company name & Risk & $\begin{array}{c}\text { Annual } \\
\text { interest rate }\end{array}$ & $\begin{array}{l}2020 \text { expenditure } \\
\text { (tax included) }\end{array}$ & $\begin{array}{l}2020 \text { income } \\
\text { (after tax) }\end{array}$ & $\begin{array}{l}2020 \text { profit } \\
\text { margin }\end{array}$ & $\begin{array}{l}\text { 19-20 revenue } \\
\text { growth rate }\end{array}$ \\
\hline E186 & $\begin{array}{l}{ }^{* * *} \text { Construction Labor } \\
\text { Service co., Ltd. }\end{array}$ & 13.29270342 & 0.04 & 1 & 1 & 0 & -1.00 \\
\hline E128 & Self-employed E128 & 12.94731484 & 0.04 & 1 & 1 & 0 & -1.00 \\
\hline E166 & $\begin{array}{l}{ }^{* * *} \text { Construction } \\
\text { Engineering Co., Ltd. }\end{array}$ & 12.17331368 & 0.04 & 1 & 1 & 0 & -1.00 \\
\hline
\end{tabular}

TABLE 12: Credit lines calculated by certain companies based on revenue growth rates in 2019 .

\begin{tabular}{|c|c|c|c|c|c|c|c|c|c|}
\hline $\begin{array}{l}\text { Enterprise } \\
\text { code }\end{array}$ & Company name & Risk & $\begin{array}{l}\text { Annual } \\
\text { interest } \\
\text { rate }\end{array}$ & $\begin{array}{c}2020 \\
\text { expenditure } \\
\text { (tax included) }\end{array}$ & $\begin{array}{c}2020 \\
\text { income } \\
(\text { after tax })\end{array}$ & $\begin{array}{c}2020 \\
\text { profit } \\
\text { margin }\end{array}$ & $\begin{array}{l}19-20 \\
\text { revenue } \\
\text { growth } \\
\text { rate } \\
\end{array}$ & Turnover & 2021 quota \\
\hline E186 & $\begin{array}{c}{ }^{* * *} \text { Construction } \\
\text { Labor Service Co., } \\
\text { Ltd. }\end{array}$ & 13.29270342 & 0.04 & 1 & 1 & 0 & -1.00 & -181 & 4078933.0 \\
\hline E128 & $\begin{array}{l}\text { Self-employed E128 } \\
{ }^{* * *} \text { Construction }\end{array}$ & 12.94731484 & 0.04 & 1 & 1 & 0 & -1.00 & -561 & 11635616.4 \\
\hline E166 & $\begin{array}{c}\text { Engineering Co., } \\
\text { Ltd. }\end{array}$ & 12.17331368 & 0.04 & 1 & 1 & 0 & -1.00 & 692 & 1171434.3 \\
\hline
\end{tabular}

I\$162486, 2019)-COUNTIFS(input invoice information!\$A2: \$A210948, A2, input invoice information! \$H $2: \$ H \$ 210948$, "valid invoice", input invoice information! \$I 2:\$I 210948,2019$)$. The specific data comparison is shown in Tables 11 and 12.

5.2. Adjust Credit Limit. For some corporate credit lines, macrocontrol can be implemented in accordance with policies. The credit line can be increased if the credit line is less than 100,000, and the credit line can be reduced if the credit line is greater than 1 million.

5.3. Improve Annual Interest Rate. According to the data analysis, if the annual interest rate is too high, it will lead to a sharp increase in the customer churn rate. Therefore, in order to ensure that the customer churn rate is less than $50 \%$, 
TABLE 13: Annex 1 correspondence between corporate risk value and annual interest rate.

\begin{tabular}{|c|c|c|c|c|c|c|c|c|}
\hline Reputation rating & Risk & Interest rate & Reputation rating & Risk & Interest rate & Reputation rating & Risk & Interest rate \\
\hline B & 0.308035 & 0.0785 & B & 0.870827 & 0.0627 & A & 2.106037 & 0.0498 \\
\hline $\mathrm{C}$ & 0.43323 & 0.0782 & $\mathrm{C}$ & 0.885318 & 0.0621 & $\mathrm{~A}$ & 2.182256 & 0.0494 \\
\hline $\mathrm{C}$ & 0.602095 & 0.0775 & A & 0.921991 & 0.0616 & $\mathrm{~A}$ & 2.211497 & 0.049 \\
\hline $\mathrm{C}$ & 0.613443 & 0.0769 & A & 0.949405 & 0.0611 & $\mathrm{C}$ & 2.259863 & 0.0485 \\
\hline $\mathrm{C}$ & 0.650022 & 0.0762 & B & 0.996121 & 0.0606 & B & 2.406582 & 0.0481 \\
\hline $\mathrm{C}$ & 0.650045 & 0.0756 & A & 1.00881 & 0.06 & B & 2.416484 & 0.0477 \\
\hline $\mathrm{C}$ & 0.652995 & 0.0749 & B & 1.017842 & 0.0595 & A & 2.423647 & 0.0473 \\
\hline A & 0.688336 & 0.0743 & B & 1.023288 & 0.059 & B & 2.588746 & 0.0469 \\
\hline $\mathrm{C}$ & 0.690585 & 0.0737 & A & 1.059018 & 0.0585 & B & 2.671114 & 0.0465 \\
\hline B & 0.692255 & 0.073 & B & 1.108265 & 0.058 & $\mathrm{C}$ & 2.807199 & 0.0461 \\
\hline B & 0.700992 & 0.0724 & A & 1.124168 & 0.0575 & $\mathrm{C}$ & 3.125604 & 0.0457 \\
\hline B & 0.703979 & 0.0718 & A & 1.12627 & 0.0571 & B & 3.303712 & 0.0453 \\
\hline B & 0.714014 & 0.0712 & A & 1.158062 & 0.0566 & B & 3.576327 & 0.045 \\
\hline A & 0.724354 & 0.0706 & A & 1.19084 & 0.0561 & $\mathrm{C}$ & 3.685514 & 0.0446 \\
\hline B & 0.727404 & 0.07 & $\mathrm{C}$ & 1.206253 & 0.0556 & $\mathrm{C}$ & 3.712288 & 0.0442 \\
\hline B & 0.738483 & 0.0694 & $\mathrm{C}$ & 1.209741 & 0.0551 & $\mathrm{C}$ & 3.856233 & 0.0438 \\
\hline B & 0.753467 & 0.0688 & $\mathrm{C}$ & 1.312666 & 0.0547 & B & 4.048533 & 0.0435 \\
\hline $\mathrm{C}$ & 0.755346 & 0.0682 & $\mathrm{C}$ & 1.360376 & 0.0542 & A & 4.377296 & 0.0431 \\
\hline B & 0.757424 & 0.0676 & A & 1.398631 & 0.0538 & A & 5.00316 & 0.0427 \\
\hline B & 0.760574 & 0.0671 & B & 1.421465 & 0.0533 & $\mathrm{C}$ & 5.164616 & 0.0424 \\
\hline B & 0.781265 & 0.0665 & A & 1.426184 & 0.0528 & $\mathrm{C}$ & 5.341012 & 0.042 \\
\hline A & 0.805959 & 0.0659 & $\mathrm{C}$ & 1.533839 & 0.0524 & B & 5.782902 & 0.0416 \\
\hline A & 0.810297 & 0.0654 & B & 1.721949 & 0.052 & B & 6.10317 & 0.0413 \\
\hline $\mathrm{C}$ & 0.828054 & 0.0648 & A & 1.824604 & 0.0515 & $\mathrm{~A}$ & 6.381905 & 0.0409 \\
\hline A & 0.830954 & 0.0643 & B & 1.832157 & 0.0511 & $\mathrm{C}$ & 6.990441 & 0.0406 \\
\hline B & 0.853665 & 0.0637 & $\mathrm{C}$ & 2.018004 & 0.0506 & B & 8.842854 & 0.0402 \\
\hline B & 0.867381 & 0.0632 & B & 2.078559 & 0.0502 & B & 9.211668 & 0.04 \\
\hline
\end{tabular}

interest rate

$$
\begin{gathered}
y=3 E-06 x^{6}-0.0001 x^{5}+0.0016 x^{4}-0.0109 x^{3}+0.0402 x^{2}-0.0767 x+0.1074 \\
R^{2}=0.9731
\end{gathered}
$$

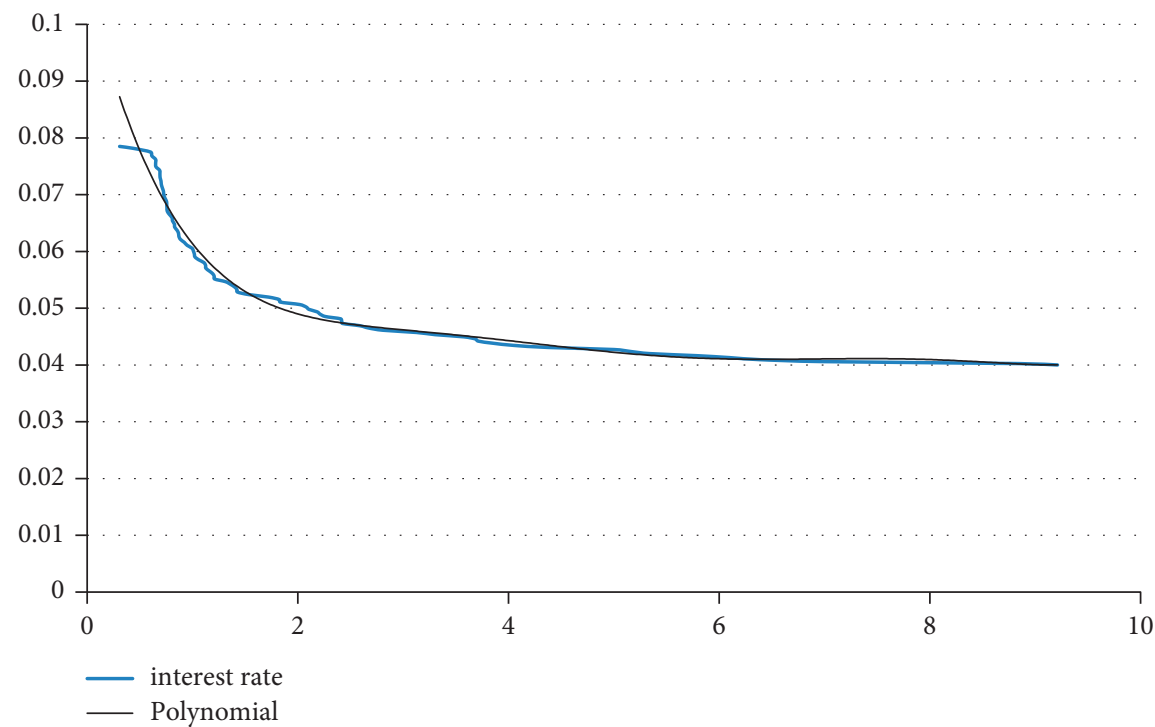

FIgURE 1: Improved annual interest rate function fitting effect diagram.

the annual interest rate can be controlled within 0.0785 . For this, we renew the annual interest rate. The function is refitted. Redivide the data in Annex 1 as shown in Table 13.

Use Excel to perform trending fitting and get an improved annual interest rate function: $y=3 E-06 \hat{x} 5+0.0016 \hat{x} 4-0.0109 \hat{x} 5+0.0402 x$

$2-0.0767+0.1074$. The fitting effect is shown in Figure 1 .

Through the calculation and comparison of the two functions $\quad(y=1 E-05 x 2-0.0122 x+0.150, \quad y=3 E$ $-06 \hat{x} 5+0.0016 \hat{x} 4-0.0109 \hat{x} 5+0.0402 \hat{x} 2-0.0767+0.1074)$, 
TABLE 14: Comparison of annual interest rate data before and after the improvement.

\begin{tabular}{lcccc}
\hline Enterprise code & Company name & Risk & $\begin{array}{c}\text { Annual interest } \\
\text { rate }\end{array}$ & $\begin{array}{c}\text { Improve annual interest } \\
\text { rate }\end{array}$ \\
\hline E418 & ${ }^{* * *}$ Marketing Planning Co., Ltd. & 4.446935282 & 0.096445142 & 0.077741233 \\
E210 & ${ }^{* * *}$ Construction Engineering Co., Ltd. & 4.443812652 & 0.09648296 & 0.077639054 \\
E151 & ${ }^{* * *}$ Road \& Bridge Engineering Co., Ltd. & 4.421320197 & 0.096755374 & 0.076911235 \\
E236 & Self-employed E236 & 4.305518904 & 0.098158044 & 0.073384643 \\
E353 & ${ }^{* * *}$ Tax Accountant Firm Co., Ltd. & 4.204064239 & 0.099387158 & 0.070582929 \\
E234 & ${ }^{* * *}$ Mechanical And Electrical Equipment Trading Co., Ltd. & 4.086490945 & 0.100811805 & 0.067647979 \\
E408 & ${ }^{* * *}$ Air Conditioning Refrigeration Co., Ltd. & 3.959225983 & 0.102354198 & 0.064819217 \\
\hline
\end{tabular}

the annual interest rate of some companies has been reduced, which has achieved the effect of reducing the customer churn rate. The specific data sample table is shown in Table 14.

During the experiment, BP neural network model, Fisher model, and logistic model are used to predict the risk of small and medium-sized enterprises [12]. According to the experimental results, compared with the other two models, the prediction accuracy of the model based on BP neural network (compared with the actual situation) is higher, which can ensure the prediction results and accuracy to a certain extent.

\section{Conclusion}

For the article's model design ideas for small, medium, and micro enterprises' credit decision-making, analysis is carried out according to the characteristics of the attached data provided by the title. First, use the fuzzy evaluation method to find the three factors that affect credit risk: reputation rating, default or not, and average profit rate, and use the addition of factor weights to get the function to calculate the credit risk value; secondly, find the function based on the risk value. The annual interest rate is used to calculate the credit limit of each enterprise through a function. According to the linear programming optimization theory, the program is used to find the best mortgage credit enterprise portfolio and provides an effective credit strategy; finally, based on the analysis of the data, analyze the operation of many enterprises. The reasons for negative growth, corporate credit lines not within the scope of bank requirements, and severe customer churn have been proposed to solve the above problems by changing the data changes in the invoicing and sales invoices of the assessed companies in 2019, adjusting the credit lines, and improving the calculation method of annual interest rates. The main advantages are as follows:

(1) The fuzzy evaluation method can prepare to find out the key factors affecting credit risk.

(2) The calculation methods of credit risk value, annual interest rate, credit line, etc. are scientific, and the result data is reasonable and reliable.

(3) Fitting based on the data in Annex 1 to ensure the accuracy of the related questions of the calculation question 2 and question 3.
(4) The mathematical model is combined with Excel to ensure the scientificity and accuracy of the model, and the C\# program is used to realize the combination problem [13], which solves the batch data that cannot be processed manually.

(5) When the sample size of the data set increases significantly, compared with other models, the accuracy of enterprise risk prediction based on $\mathrm{BP}$ neural network model is higher.

After many experiments, it was found that there are deficiencies.

The large amount of data in the invoicing and sales invoices of enterprises and the excessive number of combinations result in a relatively long time for data processing. Some programs may cause problems such as memory overflow due to excessive data volume, and the degree of program optimization needs to be improved.

\section{Data Availability}

The datasets used and/or analyzed during the current study are available from the corresponding author on reasonable request.

\section{Conflicts of Interest}

The authors declare that they have no conflicts of interest.

\section{Acknowledgments}

The authors acknowledge Guangxi Higher Education Undergraduate Teaching Reform Project (2019JGB271), Natural Science Foundation of Guangxi in 2016 (2016GXNSFAA380102), Natural Science Foundation of Guangxi in 2016 (2016GXNSFAA380188), Junior Middle School Teacher's Basic Ability Promotion Project of Guangxi in 2017 (2017KY0797), and National Social Science Foundation in 2019 (19XJY015).

\section{References}

[1] R. Zhang, "The exploration and practice of the credit loan model of technology-based small, medium and micro enterprises," China Business Forum, vol. 30, no. 16, pp. 135-137, 2021. 
[2] Z. Wang, Z. Wang, and H. Wan, "Decision-aid model based on quantitative analysis of credit risk," Information and Computer (Theoretical Edition), vol. 33, no. 10, pp. 52-56, 2021.

[3] M. Sun and H. Wang, "Application of fuzzy analytic hierarchy process to the economic evaluation of composite wood structure buildings," Journal of Northeast Forestry University, vol. 49, no. 7, pp. 111-115, 2021.

[4] W. Tao and Y. Gui, "Model research on factors affecting the high-quality development of foreign trade from the perspective of spatial measurement," Mathematics in Practice and Knowledge, vol. 51, no. 15, pp. 113-122, 2021.

[5] Z. Dong and S. Mou, "Matrix factorization recommendation algorithm based on user rating weight," Journal of Jilin Teachers College of Engineering and Technology, vol. 37, no. 5, pp. 92-94, 2021.

[6] H. Su and W. Guo, "Optimization of credit risk evaluation indexes for banks' small and micro enterprises," Finance and Accounting Monthly, vol. 41, no. 1, pp. 27-32, 2020.

[7] Y. Yu and X. Wang, "Construction of the evaluation index system for the credit ability of private enterprises--based on a survey questionnaire of 12 industries and 300 enterprises in Guangdong Province," Mathematics in Practice and Knowledge, vol. 50, no. 8, pp. 307-315, 2020.

[8] X. Zhang, N. Li, and H. Fan, "Research on the credit decision of small, medium and micro enterprises based on multiobjective planning," Contemporary Economics, vol. 37, no. 6, pp. 24-29, 2021.

[9] Y. Gu, L. Huang, C. Lin, and C. Cao, "Research on the credit model of small, medium and micro enterprises based on risk level," Software Engineering, vol. 24, no. 7, pp. 56-59+55, 2021.

[10] W. Meng, "Interest rate risk management of commercial banks in interest rate marketization," Oriental Corporate Culture, vol. 7, no. 18, p. 207, 2010.

[11] Y. Zhang, "Research on the calculation method of the compromise optimal solution of the multi-level linear programming process," Journal of Lanzhou University of Arts and Science (Natural Science Edition), vol. 34, no. 4, pp. 23-27, 2020.

[12] Y. Cheng, "Application of BP neural network in financial early warning of urban investment company," Modern business, vol. 16, no. 22, pp. 25-27, 2021.

[13] Y. Qin, "Application of an improved heuristic algorithm in solving combinatorial optimization problems," Journal of Anhui Vocational College of Electrontcs and Information Technology, vol. 20, no. 1, pp. 19-24, 2021. 